\title{
THE EVOLUTION OF THE PERSONAL PROPERTY REGISTRY: CENTRALIZATION, COMPUTERIZATION, PRIVATIZATION AND BEYOND
}

\author{
RODERICK J. WOOD'
}

This article traces the evolution of the personal property registry in Alberta from the decentralized regime of the chattel security registry which was present prior 10 1922, through the establishment of the centralized Corporate Mortgage Registry, Vehicle Registry and Central Registry, up to the present-day Personal Property Registry. Technological advances in computers and telecommunications, coupled with the prospective thinking of legislators, enabled the registry system to lead the way with innovative and efficient modes of registration and searching procedures. However, now that some registry services have been privatized, the author questions whether the impetus to continue providing improvements in the registry system have disappeared.
Le présent article relate l'histoire de l'enregistrement des sûretés mobilières en Alberta - du régime décentralisé des Chattel Security Registries en vigueur jusqu'en 1922, jusqu'à l'établissement du bureau centralisé des hypothèques, du bureau des véhicules automobiles et du bureau central d'enregistrement, pour aboutir au bureau d'enregistrement des süretés mobilières actuel. Grâce aux progrès technologiques, $\grave{a}$ l'informatisation et aux télécommunications, ainsi qu'à la vision prospective des législateurs, les modalités d'enregistrement et les procédures de recherche sont désormais innovatrices et efficaces. Cependant, suite à la privatisation de certains services, l'auteur se demande si l'incilation $\dot{a}$ poursuivre les améliorations a disparu.

TABLE OF CONTENTS

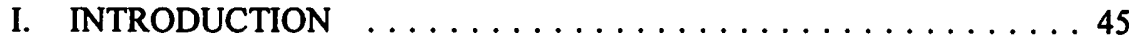

II. THE CHATTEL SECURITY REGISTRY CIRCA $1921 \ldots \ldots \ldots 46$

III. CENTRALIZATION OF THE REGISTRIES $\ldots \ldots \ldots \ldots \ldots \ldots 48$

A. THE CORPORATE MORTGAGE REGISTRY . . . . . 48

B. THE VEHICLE REGISTRY $\ldots \ldots \ldots \ldots \ldots \ldots \ldots \ldots 50$

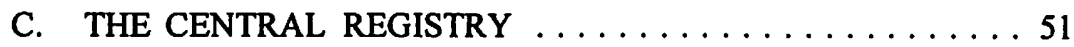

IV. COMPUTERIZATION AND CONSOLIDATION

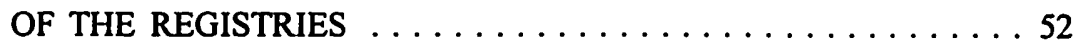

V. THE MOVE TOWARDS A PAPERLESS

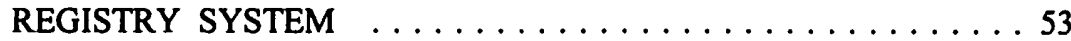

VI. PRIVATIZATION OF THE REGISTRY $\ldots \ldots \ldots \ldots \ldots \ldots 55$

VII. THE FUTURE OF THE PERSONAL

PROPERTY REGISTRY $\ldots \ldots \ldots \ldots \ldots \ldots \ldots \ldots \ldots$

\section{INTRODUCTION}

It is widely recognized that the Persoral Property Security Act revolutionized chattel security law in Alberta. The PPSA is a Canadian version of Article 9 of the Uniform Commercial Code of the United States. The genius of Article 9 lies in its insight that it is unnecessary to maintain several separate categories of security interests.

Associate Professor, Faculty of Law, University of Alberta. I wish to thank Geoff Ho and Michelle Turlock for helping me comprehend the pre-PPSA history of the registry and Bill Hurlburt for his help on the privatization debate. The opinions expressed in this article are solely my own.

I S.A. 1988, c. P-4.05 [hereinafter PPSA]. 
Instead, a unified concept of security interest was created and made subject to a single set of rules and principles. What is less well appreciated is that the personal property registry systems in Canada bear little resemblance to the comparatively primitive registry systems that are presently found in the United States. ${ }^{2}$ The genius of Canadian personal property security law lies in the sophistication of its registry systems.

This technical expertise in the design of personal property registry systems was not something that developed overnight in Alberta. It was a product of a long-standing willingness to experiment and innovate. In some cases, the impetus for change was a new advance in information technology, such as the computer, which permitted a more efficient entry and manipulation of information contained in the registry. At other times, the re-engineering of the registry was in response to some new external factor, such as the proliferation of the automobile. More recently, an ideological element has been introduced with the privatization of the registry. This article will trace the remarkable evolution of the personal property registry in Alberta over the past seventy-five years.

\section{THE CHATTEL SECURITY REGISTRY CIRCA 1921}

A relatively simple registry system existed in 1921. There were two registration statutes that governed chattel security. The Bills of Sale Ordinance ${ }^{3}$ created a registration requirement in relation to chattel mortgages. The Conditional Sales Ordinance 4 created a registration requirement that applied to conditional sales agreements and hire receipts. The registry system that existed in 1921 was based upon an old and familiar system that was first enacted in $1881 . .^{5}$ The province was divided into eleven different registration districts, ${ }^{6}$ and a registration clerk was appointed for each district. The clerk numbered each instrument submitted for registration and entered the names of the parties in alphabetical order into a book. It cost fifty cents to register and twenty-five cents for each search. ${ }^{7}$ Obtaining copies of registered documents was a labour intensive activity which commanded a fee of ten cents for every hundred words transcribed.

For a review of some of the problems with the United States registries, see E.S. Adams \& S.H. Nickles, "Mending the Article Nine Filing System to Meet Current Deficiencies" (1994) 59 Mo. L. Rev. 833; E.S. Adams et al., "A Revised Filing System: Recommendations and Innovations" (1995) 79 Minn. L. Rev. 663 at 889-910. Many of the innovative features found in the Canadian PPSA registry systems are currently being considered in connection with the next revision of Article 9.

C.O.N.W.T. 1898, c. 43. The Ordinances were renamed as Acts in 1922 when the first Revised Statutes of Alberta was passed.

C.O.N.W.T. 1898 , c. 44.

s An Ordinance respecting Mortgages and Sales of Personal Property, O.N.W.T. 1881, No.. 5. A registration requirement was imposed upon conditional sales agreements in 1889. See An Ordinance respecting Receipt Notes, Hire Receipts and Orders for Chattels, O.N.W.T. 1889, No. 8. As the West was developed, new registration districts were carved out of the eight districts which originally covered the territory which now comprises Alberta and Saskatchewan. 
Assignments of book debts were not required to be registered under provincial law in 1921. This was soon to change. The federal government had in 1919 enacted federal bankruptcy legislation after a curious thirty-nine year abandonment of the field. ${ }^{8}$ The Bankruptcy Act provided that a general assignment of book debts was void against the trustee in bankruptcy unless it was registered in accordance with provincial law. ${ }^{9}$ In 1922 The Bills of Sale Ordinance was amended so as to require registration of such assignments. ${ }^{10}$ In 1929, the province enacted The Assignment of Book Debts Act. ${ }^{11}$ This statute worked out the rules governing assignments in greater detail, but did not alter the requirement that assignments of book debts be registered in the registration district in which the debtor was located.

This did not entirely cover the field. There was, at the time, considerable uncertainty as to what kinds of secured corporate debt instruments were required to be registered under The Bills of Sale Ordinance. Chattel mortgages granted by companies were undoubtedly registerable. ${ }^{12}$ It was also accepted that floating charge debentures were not required to be registered. ${ }^{13}$ However, there were many other kinds of corporate securities, such as mortgages under trust indentures and debentures creating fixed charges, which produced a difficult and obscure case law on the scope of the bills of sale legislation. ${ }^{14}$

The registry, as it existed in 1921, might be described as a unified but decentralized system. It was unified in the sense that for each registry district there was a single registry that an interested party could search in order to determine if goods or chattels were encumbered. Chattel mortgages and conditional sales agreements (and assignments of book debts in the following year) were all registered at the same office. It was decentralized in that the search would only reveal registrations pertaining to that particular registration district.

The problem with a decentralized (or local) system is that it frequently becomes necessary to conduct multiple registrations and searches, particularly where mobile goods are involved. A decentralized registry system also necessitates a set of rules that will govern when chattels are moved from one registration district to another. Under the registration statutes, a secured party was required to file a certified copy of the

See Report of the Study Committee on Bankruptcy and Insolvency (1970) at para. 1.2.02 to 1.2.08. S.C. 1919 , c. 36, s. 30.

S.A. 1922 , c. 50 , s. 4.

S.A. 1929 , c. 8.

Capital Trust Corp. v. Yellowhead Pass Coal \& Coke Co. (1918), 10 W.W.R. 1192 (Alta. S.C.T.D.).

Johnston v. Wade (1909), 17 O.L.R. 372 (Ont. C.A.).

Imperial Canadian Trust Co. v. Wood, Valance \& Adams, Ltd. (1915), 9 W.W.R. 44 (Alta. S.C.T.D.) (mortgage to secure issue of future debentures not within scope of bills of sale legislation); Foster v. International Typesetting Machine Co., [1920] 2 W.W.R. 697 (S.C.C.) (fixed charge securing debentures within scope of bills of sale legislation). Matters were further confused in Gordon Mackay \& Co. v. Capital Trust Co., [1927] S.C.R. 374 when the Supreme Court of Canada held that, contrary to the conventional view, a floating charge was registerable under the bills of sale legislation. 
document in the registration district into which the chattels were permanently removed. ${ }^{15}$ A failure to do so within thirty days of learning of the removal invalidated the security interest. Similarly, registration of a security agreement in the wrong registration district rendered it void. ${ }^{16}$

An exception was made in the case of conditional sales agreements covering rolling stock and equipment for use on railways. Security agreements covering such equipment could be registered in the office of the Registrar of Joint Stock Companies. ${ }^{17}$ If this were done, no other registration or renewal was required and the security agreement was valid and effectual as if it had been registered in accordance with the chattel security legislation. This eliminated the need for multiple registrations in the case of rolling stock, which, by its nature, had a habit of migrating across registration district boundaries.

\section{CENTRALIZATION OF THE REGISTRIES}

A significant re-configuration of the registries occurred between 1922 and 1966 . Two new registries were created during this period, namely, the corporate mortgage registry and the vehicle registry. The creation of new registries might seem to suggest a movement away from a centralized registry system. In reality, the opposite was true. The new registries were early experiments in the design of centralized registry systems. The original decentralized registry system (the chattel security registry) with its eleven registration districts was retained, but certain types of registrations were hived off and made subject to a separate centralized system of registration. The new registry systems permitted registering parties to effect a single registration in order to perfect a security interest throughout the province. Although this piecemeal approach represented a move to greater centralization, it resulted in the abandonment of the concept of a unified registry system. This process culminated in 1966 with the centralization of the chattel security registry. The net result was that in 1966 there were three separate, centralized registry systems.

\section{A. THE CORPORATE MORTGAGE REGISTRY}

The corporate mortgage registry was established in $1922 .{ }^{18}$ All mortgages and charges created by a company were required to be filed with the Registrar of Companies. ${ }^{19}$ The corporate mortgage registry was a central registry in that there was

The Bills of Sale Ordinance, O.N.W.T. 1898, c. 43, s. 29; The Conditional Sales Ordinance, O.N.W.T. 1898 , c. 44 , as am. by S.A. 1920 , c. 4 , s. 8.

Capital Trust Corp. v. Yellowhead Pass Coal \& Coke Co., supra note 12.

The Conditional Sales Ordinance, O.N.W.T. 1898, c. 44, as am. by S.A. 1909, c. 4, s. 3. In 1965, the Conditional Sales Act, R.S.A. 1955, c. 54, s. 10 was amended so as to adopt the vehicle registry as the place for registration of conditional sales agreements of rolling stock. See S.A. 1965 , c. 15 , s. 2.

The Companies Act, R.S.A. 1922, c. 156, ss. 107-10. Prior to this, the companies statutes provided a requirement that the company keep a registry of mortgages which its creditors had a right to inspect. See The Companies Act, O.N.W.T. 1901, c. 20, s. 103.

Ibid., s. 107(1). 
a single registry that had to be searched in order to determine if a company had encumbered its assets. This obviously reduced the transaction costs associated with the financing of companies that had assets throughout the province.

The scope of the corporate mortgage registry was later modified in 1929 when newly revised companies legislation was enacted. ${ }^{20}$ The original provision provided for the registration of all corporate mortgages. The new formulation narrowed the scope of the corporate mortgage registry so that it governed a more limited subset of corporate mortgages. These included a mortgage or charge securing debentures, a mortgage or charge on uncalled share capital and a floating charge on the property of the company. ${ }^{21}$ This meant that ordinary chattel mortgages and assignment of book debts granted by a company were again registerable in the chattel security registry.

This change forced a searching party to conduct a search of two different registries in order to determine if a corporation had granted a security interest in its property. First, a search of the chattel security registry ${ }^{22}$ was needed in order to disclose the existence of conditional sales agreements, chattel mortgages and assignment of book debts granted by the corporation. Second, a search of the corporate registry was needed in order to reveal the existence of a floating charge or a mortgage or charge securing a debenture.

A benefit of this system was that it tended to segregate long-term credit transactions (as would typically be found in a mortgage debenture) from short-term credit transactions (as would generally be the case with conditional sales agreements or chattel mortgages). ${ }^{23}$ Registrations in the corporate mortgage registry were perpetual and no renewal was required. In contrast, registrations in the chattel security registry had to be renewed every three years. Although a renewal requirement was desirable in the case of short to medium term credit, it was undesirable in the case of long term financing transactions.

The Companies Act, 1929, S.A. 1929, c. 14, ss. 87-89.

The corporate mortgage provisions implicitly drew a distinction between a chattel mortgage and a mortgage securing debentures as well as between a floating charge and a fixed charge with a licence to deal. Although one might have expected these distinctions to have produced a considerable volume of litigation, this did not prove to be the case. Perhaps this was attributable to the practice of multiple registration in doubtful cases.

Once the vehicle registry was established, it became necessary to conduct a search of this registry as well if the collateral fell within the definition of an itinerant machine.

Prior to the creation of the corporate mortgage registry, a hybrid system had been created in 1907 to address the renewal problem associated with corporate debentures. The mortgage securing debentures was not required to be renewed if it were filed with the secretary of joint stock companies, who was required to keep an index of such registrations. Of course, the disadvantage of this system was that a searching party needed to undertake two searches in order to determine if the assets of a corporation were encumbered. See The Bills of Sale Ordinacne O.N.W.T. 1898, c. 43 , s. 18(2) and (3), as am. by S.A. 1907, c. 5, s. 10. This system was abandoned upon the creation of the corporate mortgage registry in 1922. 


\section{B. THE VEHICLE REGISTRY}

The movement of goods from one registration district to another poses a problem. The original registration in a different registration district is of no assistance to a party who searches in the registration district into which the goods have been relocated. The chattel security statutes addressed this problem by imposing a re-registration requirement on the secured party. Upon learning of the relocation of the goods, the secured party was given thirty days within which to re-register in the new registration district. A searching party was therefore exposed to the risk of loss if property had been removed from another registration district provided that the secured party was unaware of that fact.

The automobile possesses two unique characteristics: it is highly mobile and it maintains a relatively high resale value in the market for used goods. The latter characteristic makes it an ideal form of collateral. The former poses acute difficulties for both registering parties and searching parties who operate within a decentralized registration system. One solution to this problem is to create a central vehicle registry. ${ }^{24}$ This was the path taken by Alberta in 1951 with the establishment of the vehicle registry. ${ }^{25} \mathrm{~A}$ conditional sales contract or chattel mortgage that covered a motor vehicle was required to be registered with the registration clerk in the Motor Vehicle Branch. This eliminated the need for multiple registrations and multiple searches in different registration districts.

The vehicle registry was a manual system. A file card was prepared for every security agreement or encumbrance that was registered. The file card was indexed according to the last four digits of the serial number and bundled with other file cards having the same four digit combination. When the registration clerk received a search request, the clerk would search through the bundle of file cards having the same four digit combination and look for a registration that matched the full vehicle description and serial number. ${ }^{26}$

The creation of the vehicle registry provided searching parties with an additional advantage. Security agreements registered in the vehicle registry were indexed by serial number. A search using the serial number therefore disclosed security interests granted by the current owner, and also revealed any security interests that may have been given

It is not the only solution to the problem. Article 9 of the Uniform Commercial Code provides that an Article 9 filing is not required where the collateral is subject to a state certificate of title statute. Certificate of title systems are widely utilized in the United Sates for automobiles, boats and other forms of mobile goods. See G. Gilmore, Security Interests in Personal Property, vol. 1 (Boston: Little, Brown, 1965) at 550-578 (description of state certificate of title statutes and their relationship to Article 9); I. Davies, "The Negotiability of Motor Vehicles in England and New Zealand: A Conundrum for the Common Law" (1995) 16 N.Z.U.L.R. 275 (comparing certificate of title systems with asset registration systems). An Act to Amend the Bills of Sale Act, S.A. 1951, c. 7; An Act to amend the Conditional Sales Act, S.A. 1951 , c. 15 . 
by a prior owner of the motor vehicle. ${ }^{27}$ However, a search of the vehicle registry by debtor name could not be undertaken since only the serial numbers were indexed and available as a search criterion.

The vehicle registry was expanded to encompass additional types of mobile goods. The exploitation of oil in the province gave rise to a new registration problem as oilwell drilling equipment migrated around oil-producing portions of the province. The expanding commercial use of aircraft created similar problems. In 1953, the motor vehicle registry was widened so as to cover oil-drilling equipment, trailers and aircraft. ${ }^{28}$ Aircraft and trailers were eventually required to be registered by serial number. ${ }^{29}$ However, oil-drilling equipment did not possess a unique serial number, and therefore these registrations continued to be indexed in the vehicle registry using the name of the debtor.

\section{THE CENTRAL REGISTRY}

The final phase in the centralization of the registries occurred in 1966 with the enactment of the Chattel Security Registries Act. ${ }^{30}$ The Act abolished the system of registration districts and, in its place, established a central registry located in Edmonton. ${ }^{31}$ The statute did not unify the three registry systems; the corporate mortgage registry and the motor vehicle registry remained outside and unaffected by the legislation.

The central registry introduced an automated registration and search system. The actual security documents that were submitted for registration were microfilmed and returned to the registering party. A synopsis setting out the type of registration, the parties, the nature of the collateral and the amount secured was prepared by the registry staff. The synopsis was then given a code based on the characters in the name. A search of this microfilm was automated so that a scanner stopped whenever the code of the name being searched matched with the code associated with a registration. The operator then conducted a visual inspection to determine if the name searched matched that of a registration. If it did, a copy of the synopsis was provided to the searching party. ${ }^{32}$ If the searching party wished to examine the security agreement, a further search of the microfilmed records was required.

27 A search of the chattel security registry could only be undertaken using the debtor name as the search criterion. This would not disclose a security interest that had been granted by a person other than the debtor. An Act to Amend the Bills of Sale Act, S.A. 1952, c. 17; An Act 10 Amend the Conditional Sales $A c t$, S.A. 1952, c. 17. The legislation used the term "itinerant machine" to refer to the classes of mobile goods which fell within the vehicle registry.

An Act to Amend the Bills of Sale Act, S.A. 1971, c. 9, s. 2 amending S.A. 1952, c. 17. An Act to Amend the Conditional Sales Act, S.A. 1971, c. 18, s. 2 amending S.A. 1952, c. 17. Prior to this, security interests in aircraft and trailers were indexed by debtor name in the vehicle registry. S.A. 1966, c. 12.

31 Ibid., ss. 5, 7. Although the statute provided for branch offices where the documents could be tendered, the registration was not effective until these were transmitted to Edmonton and assigned a registration number.

32 See N. Nichols, "Nichols: Comment on the Registry System" in Nozick, supra note 26 at 246. 
One of the problems with centralization is that access to the registry becomes more difficult for distant registering and searching parties. Remote parties who wish to search a central registry may be subject to substantial delay when registering by mail or the expense of traveling to the central registry to expedite a registration. However, as the costs of speedy communication decline, the benefits of centralization dominate. A revolution in telecommunications made near instantaneous communication between distant locations a possibility, and the barriers which impeded centralization quickly disappeared. The central registry was established during this period. The central registry took full advantage of this new technology by establishing a series off branch offices where out-of-town parties were able to register and search by tele-type.

\section{COMPUTERIZATION AND CONSOLIDATION OF THE REGISTRIES}

The co-existence of three separate, centralized registry systems, although understandable, was a less than utopian state of affairs. Multiple registries entail multiple searches. A searching party would often need to undertake as many as four separate searches (the three provincial registries and the federal Bank Act security registry). There was also uncertainty in some cases as to which registry was the proper place for registration. This led to the practice of dual or multiple registrations.

This problem obviously could be solved by consolidating the registries into one unified and centralized registry system. It was at the technical level that implementation of this solution presented problems, since it required the conversion of records and the integration of different registration rules and procedures. An initial step towards unification occurred in 1983 with the computerization of the records in the central and vehicle registries. ${ }^{33}$ The central registry contained approximately half a million registrations. The synopses relating to these registrations were manually converted from microfilm to computer database in an astonishing display of brute secretarial power. The same approach was not used in relation to the vehicle registry as there were approximately 2.2 million motor vehicle cards on file. Instead of converting the existing records, the manual system was phased out over three years by requiring new registrations and renewals to be updated to the computer database. ${ }^{34}$

The 1983 amendments also introduced the financial interest statement - the precursor to the $P P S A$ financing statement. A registering party was required to prepare a financial interest statement giving details of the security agreement. ${ }^{35}$ The financial interest statement was then submitted with the security agreement for registration. This effectively transferred the responsibility for preparing a synopsis of the information from the registry staff to the registering party.

Although the registries were located in the same building and served by the same computer, the central registry and the vehicle registry were not actually unified in any

Chattel Security Registries Act, S.A. 1983, c. C-7.1.

The computerization of the registries is briefly described by lan Murray in Nozick, supra note 26 at 249.

Chattel Security Registries Regulation, Alta. Reg. 133/84, s. 17. 
real sense. Separate registrations and separate searches were still required. A secured party who took a chattel mortgage covering trucks and cattle had to register a financial interest statement covering the cattle in the central registry and a financial interest statement covering the trucks in the vehicle registry. Equally, a search of the central registry using the debtor name would disclose the registration covering the cattle, but not the registration covering the trucks.

The ideal of "one big filing system" ${ }^{36}$ was finally realized after the coming into force of the Personal Property Security Act in 1990. The 1983 amendments to the Chattel Security Registries Act had anticipated the eventual enactment of the PPSA, and had been designed to facilitate the transition from the old system to the new. The computerization of the records in the central and vehicle registries ensured that this data was in a form that could be readily absorbed into the new Personal Property Registry.

A more significant transition problem involved the corporate mortgage registry. The documents contained in the registry spanned a period of more than seventy years. Many of the registrations were stale. In many cases, there had been corporate reorganizations, amalgamations or changes in name. Conversion was not thought to be a feasible option, and so it was decided to phase out the corporate mortgage registry over three years. ${ }^{37}$ The onus was on the registrant to re-register under the PPSA before the three year period expired. This period ended on October 1, 1993, and this date therefore marks the when a single, centralized provincial registry was finally achieved.

A major innovation introduced by the PPSA was the concept of a notice registration system. The pre-existing chattel security registries were all built upon a document filing concept which required the actual security documents to be filed at the registry. Under a notice registration system, the security agreement is not filed. Instead, a financing statement is registered. This document sets out only the essential details of the transaction. Here, too, the transition was made less difficult because of the 1983 amendments. Registering parties were already accustomed to completing a document (the financial interest statement) that was not unlike a financing statement. The biggest change in procedure was that the registering party was no longer required to submit the security agreement for registration.

\section{THE MOVE TOWARDS A PAPERLESS REGISTRY SYSTEM}

When the PPSA first came into force in Alberta, it utilized a paper-based registration system. In order to effect a registration, a party was required to submit a prescribed form of document, called a financing statement, to the registry in Edmonton. The registry staff would then input the information contained on the financing statement to

This expression was used by Gilmore, supra note 24 at 465 . This ideal was never ultimately realized in the United States. A significant number of states maintained some variation of a decentralized local filing systems. As a consequence, there are more than 4200 separately searchable UCC filing systems in the United States. See L.M. LoPucki, "Computerization of the Article 9 Filing System: Thoughts on Building the Electronic Highway" (1992) 55:3 Law \& Contemp. Prob. 5 at 16. 
the computer database. However, the legislation, from the outset contemplated that registration in the future might be effected electronically from remote locations. The definition of "financing statement" covered a printed financing statement, but also extended to "data authorized under the regulations to be transmitted to an Office of the Registry." ${ }^{138}$

In November 1991, the Registry commenced a pilot project under which approximately twenty customers were given computer access to the Registry database. This permitted the customer to search the database, but did not initially permit electronic registration of a financing statement. The pilot project was a success and remote access to the database was extended to 337 clients in August 1992. In January 1994, the Registry permitted registrations to be effected by remote registration, and on October 1994 remote amendments and discharges were permitted through the electronic communications system.

The online registration and search capability was a development of fundamental importance. A lawyer or employee of a financial institution could register, amend or discharge a registration and could search the computer database from his or her office. Jurisdictions which implemented this feature soon found that the vast majority of searches and registrations were occurring through the electronic communications system. ${ }^{39}$ Searches and registrations could be undertaken more quickly than in the past. There were also considerable efficiency gains, since electronic registration eliminated the need for the registry staff to manually input the data from a printed financing statement into the computer database. Although not contemplated at the time, remote registration also put into place a critical element needed for the privatization of the registry.

Although an electronic registration system produces an almost instantaneous ability to register and search, there are also some costs associated with a paperless system. The resolution of a priority competition may turn on proof of the perfected status of a security interest at a particular point in the past. A search of the registry will disclose the original registration and will also show any subsequent amendments made to the registration. However, if the registration lapses or is discharged, it is purged from the computer database and a search of the registry will obviously not reveal this information. Before the advent of electronic registration, every financing statement and financing change statement was microfilmed. It was therefore possible to reconstruct a lapsed or discharged registration by following its paper trail. An unfortunate byproduct of a paperless registration system is that this procedure is no longer available where the electronic communications system is used.

Ibid. at s. 1(1)(p).

For example, in British Columbia 90.5 percent of the registrations and 90.7 percent of the registrations were effected using the remote electronic communications system in 1995 . See Minutes of the 1996 Canadian Conference on Personal Property Security Law - Provincial Updates. Statistics are not available for Alberta since Alberta registry officials have not participated in the Conference since privatization of the registry. 


\section{PRIVATIZATION OF THE REGISTRY}

In December 1992, Ralph Klein took over as premier of the province, and on June 15, 1993 the Klein government was elected. In the throne speech, a radical program of deficit elimination, debt reduction and privatization was announced. ${ }^{40}$ Responsibility for the registries was transferred from Justice to Municipal Affairs. The operation of the Personal Property Registry computer, Perpis, together with the computer information systems for the Land Titles Office, the Corporate Registry, the Motor Vehicles Registry and Vital Statistics were contracted out to SHL Systemhouse Inc. under a seven year contract. $^{41}$

The delivery of registry services to the public was privatized on February 1, 1994. These services covered non-electronic registrations and searches. Prior to this date, government employees (the registry staff) were responsible for entering the data contained on printed financing statements into the computer database. The registry staff were also responsible for processing searches, which could be requested by mail, fax, telephone or in person. These functions were contracted out to private registration agents. This transfer of responsibility was part of a much larger plan which involved the privatization of a vast range of government registry services. The private agents were also given responsibility for driver's licences, motor vehicle licensing, corporate searches, land titles searches, vital statistics (including marriage licences and birth and death certificates) and hunting and fishing licences. There are approximately 225 registry agencies in the province, with about thirty each in Edmonton and Calgary.

Privatization immediately resulted in a significant increase in the price of services. For example, the average price in Edmonton for a debtor name search increased from $\$ 5.00$ to $\$ 9.28$, and the price of a PPSA registration with a three year registration life rose from $\$ 12.00$ to $\$ 20.29 .^{42}$ Users of electronic communications system (Alberta Online) were unaffected by privatization and continued to register and search electronically under the prior fee structure. Not surprisingly, registry agents began to covet the registration and search activity that parties could undertake on their own behalf through Alberta Online. The government responded initially by putting a moratorium so that no new access to Alberta Online could be obtained. Of course, this had the effect of creating a significant barrier to entry by imposing higher costs on new credit grantors and law firms.

The imposition of a moratorium was not well received by the practising bar and other frequent users of the system. The moratorium was subsequently terminated. However, in order to appease the registry agents, the government froze the registry services provided through Alberta Online by stipulating that any new offering of registration services would be provided exclusively by the private registry agents. Writs

40 See Alberta Hansard (30 August 1993) at 4.

"W.H. Hurlburt, "Developments in the Land Titles System" in Canadian Bar Association/Law Society of Alberta Newsletter (Sept/Oct 1994) at 12.

42 These figures are based upon an August 1, 1995 telephone survey of twenty registration agents located in Edmonton. 
of enforcement were the first victim of this policy. A sensible approach would have been to permit online registration by the lawyer who obtains the writ. Instead, the lawyer must take the more costly and time-consuming step of having it registered through a private registry agent. Rather than producing efficiency gains, privatization appears to have produced rent-seeking behaviour on the part of private registry agents. $^{43}$

Another unsettling feature of the privatization concerns the issue of legal liability for errors. Prior to privatization, there existed a sharp distinction between printed financing statements delivered to the registry and remote registration through the electronic communications system. In the former, a printed financing statement was delivered to the registry and data entry was undertaken by the registry staff. The registry was liable for loss caused by an error in entering this information into the computer database, and an assurance fund was established to meet such claims. If electronic registration was chosen, the registering party had no claim against the assurance fund for any system failure that caused an error in transmission of data. ${ }^{44}$

Since privatization, the issue has become more complex. If a printed financing statement is submitted to the registry agent, the position is no different than in the past. The problem arises when registry agents offer value-added services to their customers. This may occur if a registry agent agrees to accept information in a form other than a printed financing statement. It may also occur if a registry agent agrees to assist a customer in assembling the information that is to be registered. These activities do not fit easily within the liability regime set out in the PPSA. Although the PPSA insulates registry employees and officials from liability for loss, this provision might reasonably be restricted to cases where the registry agents are acting in their usual capacity. ${ }^{45}$

\section{THE FUTURE OF THE PERSONAL PROPERTY REGISTRY}

We have observed, in Alberta, a progressive centralization and consolidation of the registry systems until the ideal of "one big filing system" was ultimately realized. A similar process occurred in other Canadian provinces which enacted a PPSA. However, when this collection of provincial PPSA registries is viewed from a national perspective, it becomes apparent that many of the attributes of a decentralized registry system are present. The major difference is that it is now the provinces which comprise the individual registration districts. Should we predict that the same tendency to centralization will take hold and result in a single personal property registry system organized on a national level? I suspect that this will not occur, at least not in the foreseeable future.

43 Rent-seeking is the expenditure of resources to search out existing monopoly rights or to lobby for the creation of new monopoly rights.

4 Section 52(1) of the PPSA gives a person a cause of action against the Registrar to recover any loss caused by an error or omission relation to a printed financing statement. Section 52(4) bars all other actions against the Registrar or an office or employee of the Registry.

45 Where no printed financing statement is submitted to a registry agent, no action against the Registrar will lie under section 52(1) of the PPSA. The issue then will be whether the registry agent will nevertheless be able to avail itself of the protection in 52(4). 
The transition to a national system would not be easy. The present provincial registry systems vary widely. There is a fundamental difference in the collateral description contained in the Ontario registry and that found in the other provincial registries. Even among provinces that use the same model Act, there are significant differences in the information that is required to be registered. Perhaps the greatest impediment to a national registry system is that it would require a major effort on the part of the federal government and the provinces to coordinate their efforts in an area in which the federal government has virtually no technical expertise. There are also some disadvantages associated with a national registry system. For example, a national registry would greatly magnify the problem of similar names. A search of the name Joseph Smith under a national registry system would disclose all similarly named debtors from coast to coast.

In the past, centralization produced considerable efficiency gains by reducing the amount of time and effort needed to conduct multiple registration and searches in several jurisdictions. Remote registration and access has greatly reduced the cost of multiple registration and searching, and therefore the benefits of centralization are simply not as great as they once were. A more likely scenario is a movement towards uniformity in the format of financing statements. The development of a standard form financing statement and search request would permit the same data entry to be used to electronically register or search in several different provincial registries. This would further reduce the cost of undertaking multiple registration and searches. Furthermore, there presently exists an umbrella organization under which such efforts might be undertaken. ${ }^{46}$

The decision to privatize the personal property registry may prove to have serious and unanticipated ramifications. The registry, immediately prior to privatization, was rapidly undergoing a metamorphosis all on its own. The overwhelming majority of registrations were effected through the electronic communications system. The majority of searches were also conducted through this means. In a sense, the registry was privatizing itself. ${ }^{47}$ This process has been retarded by the absurd policy decisions which accompanied privatization, such as the restriction on the kinds of registrations that can be effected through the electronic communications system.

Perhaps a greater threat comes from the government's attitude that privatization has freed it from any burden of responsibility for the registry. There is no longer any

The Canadian Conference on Personal Property Security Law ("CCPPSL") was established in 1991. Its membership is made up of provincial registry officials, government policy analysts and legal academics. The original goal of the CCPPSL and of the Western Canada Personal Property Security Act Committee which it replaced was to produce a model PPSA which could be adopted by provinces wishing to reform their chattel security law. This task is largely finished and the work of the Conference is increasingly directed towards achieving uniformity or harmonization at the operational level.

4 During this period there was a significant reduction in the registry staff as the need for the manual inputting of data diminished. Prior to the PPSA, there were 110 registry staff. Upon the coming into force of the PPSA this had been reduced to approximately sixty. By 1992, the number had been further reduced to fifty. 
inclination to take an active role to improve the operation of the system or to coordinate efforts with the other provinces. ${ }^{48}$ There is a serious possibility that the present registry system will become ossified. This would be a most unfortunate development. There are exciting possibilities on the horizon. British Columbia is on the verge of implementing a second generation algorithm which will significantly improve the close similar match capability of the registry. ${ }^{49}$ New Brunswick has moved to a completely paperless registry system. Alberta, which traditionally has been on the forefront of such developments, appears no longer to be a player. We should be saddened to see this fine tradition wither away.

Registry officials from Alberta no longer participate in the Canadian Conference on Personal Property Security Law. The government no longer supports the production of the Registry Information Guide (1992), which is still widely used notwithstanding that it is badly out of date. The government also has discontinued a consultative process in which input was obtained from frequent users of the system with a view to improving the delivery of service. approximate the search criterion used in a search. For example, a search using Rodney Smith will also disclose Rod Smith and Roderick Smith. The Alberta registry system currently uses the NYSIS algorithm, which has the tendency to also disclose as similar matches names that are only distantly related to the search criterion. See R.C.C. Cuming \& R.J. Wood, Alberta Personal Property Security Act Handbook, 2d ed. (Toronto: Carswell, 1993) at 336-38. 